\title{
Alternatives to social housing: Applicants' views of various policy options
}

Privatisation of a large share of the housing stock was characteristic of all central and eastern European countries, which left the majority of these countries with an impoverished social housing sector and therefore little opportunity for housing most vulnerable groups. Even though it was envisaged that this sector would gradually develop, this has not happened in Slovenia. This article analyses the acceptability of a limited number of alternative housing solutions. The alternatives were evaluated by applicants for social housing in the Municipality of Ljubljana. The survey was carried out by post and targeted unsuccessful applicants for social housing, with 1,048 respondents. On the basis of hierarchical cluster analysis, we identified three distinctive groups of applicants in relation to the acceptability of alternative housing options: those preferring shared homeownership (and social rental housing), those open to all alternatives, and those with a strong preference for social rental housing. Our findings thus demonstrate that applicants for housing vary significantly in their readiness and means to more actively engage in their housing solutions, but only if there are opportunities available.

Keywords: housing policy, social housing, housing preferences, Ljubljana, alternative housing options 


\section{Introduction}

Privatisation of a large share of the housing stock was characteristic of all central and eastern European (CEE) countries (see Turner et al., 1992; Clapham et al., 1996; Struyk, 1996; Hegedus et al., 1996; Mandic 2010; Tsenkova 2014), which left the majority of these countries with an impoverished social housing sector and therefore little opportunity for housing most vulnerable groups. Even though it was envisaged that this sector would gradually develop, this has not happened in Slovenia partly also due to late adoption of a new housing policy (five years after privatisation) and a constant lack of financial resources for this sector as well as institutional issues (see Cirman, 2007; Mandic, 2007; Sendi, 2007, 2013; Kušar, 2012). Similar developments were typical in the region because extension of the social housing sector has typically been minimal, and social and financial sustainability of the new social housing stock is very weak (Hegedus, 2011; Lux \& Mikeszova, 2012; Lux \& Sunega, 2014).

In addition to low availability, social housing also has some additional problems. First are relatively low spatial standards; that is, the size of housing is generally small. Another is relatively high housing costs. This is especially problematic due to the fact that housing costs have increased since the transition from communism as a result of price liberalisation, and consequently housing costs have increased in transition countries much more than household incomes (Hegedus, 2011). This is true also for the case study selected for this article, the city of Ljubljana, because the housing is usually relatively small and old, with high housing costs (see Filipovič \& Mandic, 2007). The providers of social housing in Slovenia are predominantly municipal housing funds, other providers are few, and alternative housing options are rare. Municipal funds are too small to allow the development of a social housing sector to enable a sufficient supply in line with the rising needs of the most vulnerable members of society. Additional pressure is put on the funds due to the economic crisis, which also increased the vulnerability of households. This article analyses the acceptability of a limited number of alternative housing solutions for the regular non-profit sector. The alternatives were evaluated by applicants for social housing in the Municipality of Ljubljana. We sought to determine whether applicants have the means and preferences to also look at alternative ways to improve their housing situation outside the social rental sector, which would have important implications for housing policy (e.g., possible introduction of new instruments and less pressure on the social housing sector). This issue is also of interest in relation to the widespread popular beliefs in Slovenia that stigmatise claimants for social housing as avoiding personal responsibility and financial engagement for their own housing, and instead pass- ing the burden on to the society or state. This issue is widely discussed in the social sciences, particularly in the debate on "welfare dependency" versus "active citizenship" (see TaylorGooby, 1993; Dwyer, 2004; Robinson, 2013). Building on the argumentation of Peter Taylor-Gooby (2001) that welfare claimants' actions are dependent on the social and economic resources that they have at their disposal, we hypothesise that, among the applicants for housing in Ljubljana, the acceptability of diverse housing options vary and that acceptability of various options is related to applicants' means.

The structure of the article is as follows. First we present the housing sector in Slovenia and Ljubljana. Then we reflect on possible alternatives to social housing through a literature review. We continue by presenting the survey methodology and survey results. We present the current housing conditions of applicants for social housing and their financial and other resources (e.g., use of welfare state support and family support). We then present how applicants evaluated the following alternative housing options: smaller social housing, housing built to passive standards, shared homeownership, temporary social housing, a housing cooperative, and cheaper purchase of housing on the market. A cluster analysis was performed to test the hypothesis that the acceptability of options varies among applicants.

\section{Housing vulnerability in Slovenia and the city of Ljubljana}

Housing exclusion and vulnerability in Slovenia is increasing. Housing vulnerability and housing exclusion is understood in this article in relation to the concept of housing exclusion as proposed by Bill Edgar and Henk Meert (2005) and Meert et al. (2004). The authors define housing vulnerability and exclusion based on three dimensions: legal, physical and social. Those suffering housing exclusion are excluded in one or more dimensions; for example, illegal occupancy or renting without a contract (the legal dimension), housing unfit for habitation or substandard housing (the physical dimension), and housing that does not enable normal social interaction - for example, in cases of overcrowding (the social dimension). These are conditions in which many of the applicants for social housing find themselves, and therefore they represent the population studied here. We also link this vulnerability with poverty and low income, which is again characteristic for people living in precarious housing conditions.

Housing exclusion can be linked to several reasons, ranging from personal and relationship causes to organisational and structural causes (Edgar et al., 2006). For Slovenia, Srna Mandic and Maša Filipovič (2008) have already emphasised the im- 
portance of structural causes linked to homelessness and housing exclusion. One of the main structural reasons for housing vulnerability is changes in the housing sector in the transition and selling of a large proportion of social rental stock, slow further development of social rental housing and slow development of other housing options for vulnerable groups. According to public census data, only $9 \%$ of housing was rented in 2011 (this Figure includes both private and public rentals; Statistical Office of the Republic of Slovenia, 2011), and the size of the public housing stock is approximately $7 \%$.

These circumstances were accentuated when the current economic and social crisis hit Slovenia in 2008, which led to an increasing vulnerability of certain groups - mostly the unemployed, the homeless and single-parent families. Registered unemployment decreased in the period from 2000 to 2008 to record low numbers in the history of Slovenia as an independent state. After that period, it started rising rapidly, reaching higher rates than those in the 1990s (the number of registered unemployed in June 2012 was 105,630). The unemployed have been affected most because the at-risk-of-poverty rate has risen from $25.1 \%$ in 2005 to $44.2 \%$ in 2010. Along with the unemployed, the at-risk-of-poverty rate is also very high among the elderly (the $65+$ group: $20.9 \%$ in 2010 ) and among specific households, such as single households ( $40 \%$ in 2010) and single-parent households (30.8\% in 2010; Statistical Office of the Republic of Slovenia, 2011). Vulnerable groups are usually more numerous in larger urban areas, which often also become the focal point for the vulnerable from surrounding (rural) areas due to better job opportunities, more housing options and more developed support services.

Growing financial and material vulnerability is linked to growing housing vulnerability among homeowners and renters, who have difficulty paying housing costs and paying for the upkeep of housing. A significant share of households in Slovenia consequently suffers housing deprivation. The share of such households has been increasing in recent years, showing a negative impact of the economic crisis on the housing situation. The share of those deprived of at least one item on the housing deprivation list almost doubled from 2005 to 2010 (18.4\% in 2005 and $31.2 \%$ in 2010; Eurostat, 2014). General accessibility in the homeownership sector is poor, also due to increasing housing prices (the average sale prices of apartments grew by nearly $80 \%$ from 2003 to 2007; Surveying and Mapping Authority of the Republic of Slovenia, 2008 ${ }^{[1]}$ and has depended to a large extent on family support ${ }^{[2]}$ (see, e.g., Cirman, 2006). Even though the crisis affected prices, the accessibility of this sector is still poor for the most vulnerable because they have difficulty obtaining loans from banks.

For the most vulnerable, a key instrument is social housing, which provides individuals and families with lower incomes

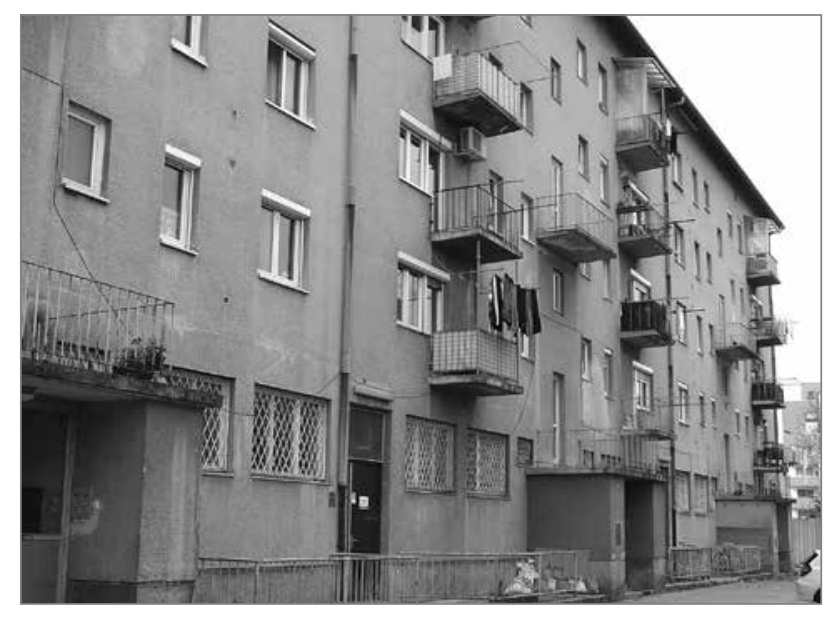

Figure 1: Housing exclusion and vulnerability in Slovenia is increasing (photo: Boštjan Kerbler).

access to housing. In Slovenia, the local authorities are the most common provider of social housing, and in the city of Ljubljana this sector is most developed (compared to other parts of Slovenia). ${ }^{[3]}$ However due to the small social housing sector, the supply of this housing is significantly lower than the demand for it, which results in the majority of applicants being rejected. Even though the municipality and the Public Housing Fund are active in providing housing for vulnerable groups and developing the social housing sector was envisaged in housing programmes, the needs significantly exceed the supply. The size of the sector is small (with $8.7 \%$ of households living in social housing), especially when one compares this with other urban capitals in Europe. For example, in the Municipality of Ljubljana, the yearly rate of approved applicants for social housing ranges from $6.8 \%$ (in 1995) to $9.7 \%$ (in 2005; Hegler, 2006). Even though this has slightly increased in recent years, it still reaches only around 14\% (Public Housing Fund of the City of Ljubljana, 2011). The Municipality of Ljubljana also supplies emergency units for the most vulnerable and the waiting lists are also quite long. ${ }^{[4]}$ Along with low availability, social housing also has some additional problems. First are relatively low spatial standards; that is, the size of housing is generally small, which is a problem common to the housing stock of transition countries (see Mandic \& Cirman, 2012). The other is relatively high housing costs. Masa Filipovič and Srna Mandic (2007) have shown in their research on the Municipality of Ljubljana that many households (not limited to those in social housing) are overburdened by housing expenses (i.e., $17 \%$ have housing expenses higher than $30 \%$ of their income). This is especially pronounced among single-parent households ( $41 \%$ are overburdened) or in poor households (63\% of households are overburdened). This discrepancy between supply and demand in the social housing sector, and the poor ability of the vulnerable to enter and/or remain in the homeownership sector indicates that some alternative housing option would be needed to accommodate these groups. This article examines what kinds of alternative housing options would be acceptable 


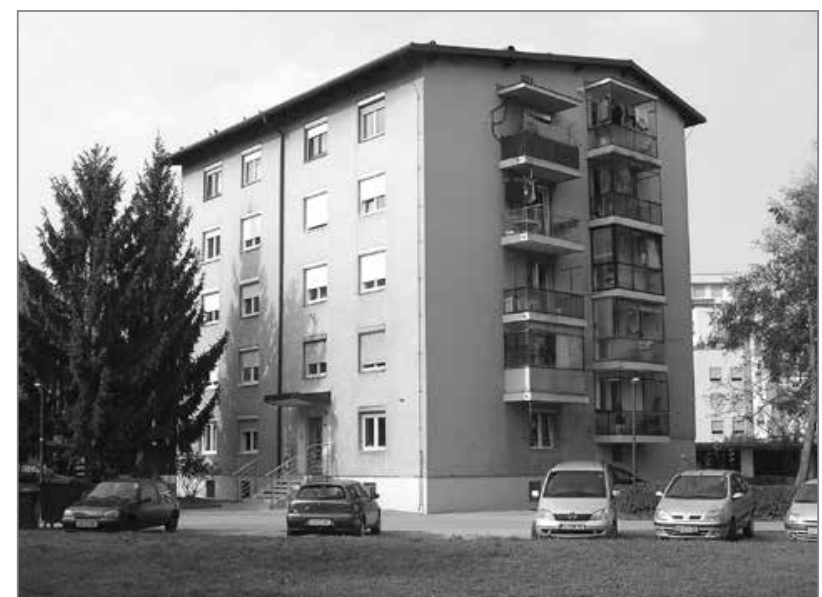

Figure 2: Social housing in Slovenia is characterised by low spatial standards; the size of housing is generally small, which is a problem common to the housing stock of transition countries (photo: Boštjan Kerbler).

to the most vulnerable groups (according to their available resources) based on a survey among applicants for social housing in the Municipality of Ljubljana.

\section{Additional housing options}

The social or non-profit sector in Slovenia is small and supplied to a large degree by various municipal housing funds, but there has not been much interest in its quality issues, or in new models and providers. As a contrast, there seems to be growing interest in various aspects of social housing in Europe. Under discussion are not only general issues of social housing modernisation (see Baldini \& Poggio, 2012; Muir, 2013; Leather \& Nevin, 2013; Forrest, 2014; Lévy-Vroelant, 2014), but also more specific issues, such as security of tenure (Hulse \& Haffner, 2014; Hulse \& Milligan, 2014; Fitzpatrick \& Pawson, 2014) and, most importantly, also new models and providers of not-for-profit housing (Blessing, 2012; Pawson \& Sosenko 2012; Morrison, 2013). In various European countries, however, the social housing sector can be set up quite differently with regard to who the provider is or how this sector is financed (see Andrews et al. 2011; Pittini \& Laino, 2012). Providers can range from the public (e.g. local municipalities) to private landlords (non-profit cooperatives, and private and public partnerships). A study by Richard Polacek et al. (2011) distinguished four models of social housing provision in $\mathrm{Eu}-$ rope. The first model is one in which the public authorities are the direct provider of social housing (most often using municipal funds or other public funds if available). In the second model, the public authorities have the right to part of dwellings owned by private companies that own social housing. In the third model, private landlords have a verified status and must obey regulations (of rent-setting, etc.). The fourth model

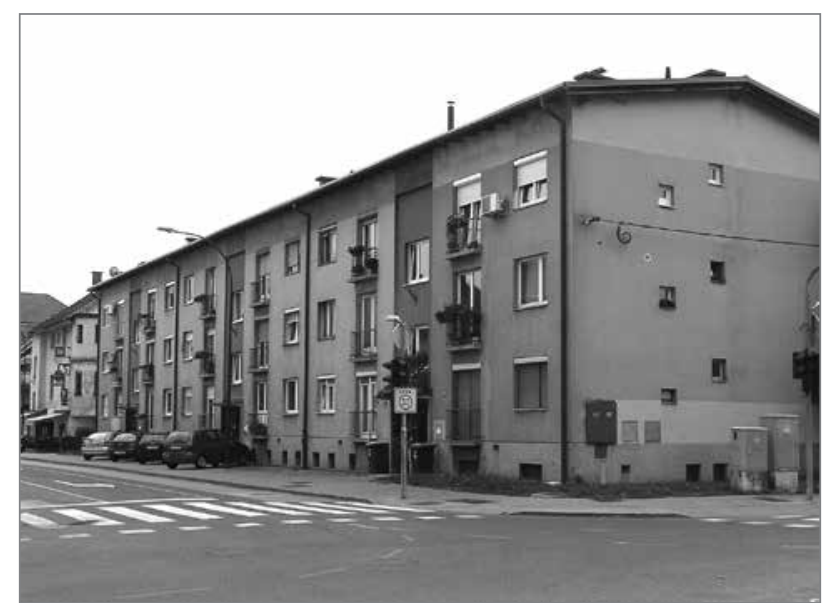

Figure 3: In many European countries, housing cooperatives are a major provider of affordable housing; in Slovenia there are no housing cooperatives of the standard type (photo: Boštjan Kerbler).

encompasses public financial schemes, which offer financing of social housing. One can find a mix of different models in one country. In Slovenia, one can also find various models, although not to a great extent. Providers vary from municipalities or municipal housing funds to private companies offering social housing in some cases. However, the predominant model is one in which municipalities play the major role and other models are poorly developed.

In Slovenia, housing cooperatives, although they have a legal foundations, are practically non-existent. Before the Second World War, they existed in a number of cities. However, under communism, a new model of building cooperatives was introduced, receiving tax deductions for purchasing building materials and mostly dissolving after the construction process was completed and housing units were transferred to private property. This model disappeared with the Housing Act in 1991, when tax deductions were also abolished. After that, housing cooperatives were not promoted by an agency or private initiative. In many EU countries, housing cooperatives are important providers of housing for vulnerable groups. Because self-building has traditionally been an important way of improving the housing situation for a significant proportion of people in Slovenia, one could also develop alternatives in which individuals' participation would be encouraged and subsidised. Examples of such models implemented abroad are transfer of degraded housing to individual owners or cooperatives, who renovate the housing at their own cost (the Dutch example in Rotterdam), or unfinished housing, which is therefore cheaper (e.g., first-time homes for young couples in Italy; see Mandic et al., 2012). There are various options for providing affordable housing. ${ }^{[5]}$ Another important alternative is a mix of rent and ownership. UN-HABITAT ${ }^{[6]}$ emphasises the need for various funding methods, including cooperatives, 
Table 1: Type of applicants by age

\begin{tabular}{lll}
\hline & List A & List B \\
\hline Average & 41.58 & 42.15 \\
\hline Standard deviation & 11.54 & 10.94 \\
\hline
\end{tabular}

loans (through special banks that offer micro-loans with lower interest rates), renting to own (purchase of housing through instalments and rent), national financing and subsidies (lowering rent, or subsidies for building material). However, because the alternatives described above are not well known, it is important to study the potential attitudes toward these options, which options receive more support and who supports specific options. This is presented in the empirical part of this article.

\section{Methodology}

In the light of the circumstances described, we now present a recent study among applicants for social housing in the city of Ljubljana. The study was commissioned by the Public Housing Fund of the Municipality of Ljubljana, which also supplied the list of unsuccessful applicants for social housing for the survey, carried out by post. As already mentioned in the previous sections, due to the lack of social housing each year, there are many applicants for social housing that, even though they do fulfil the criteria to receive a social housing unit, they do not receive one (because the number of applicants is much higher than the number of units offered by the Public Housing Fund). The Municipality of Ljubljana supplied the addresses of all the unsuccessful applicants and sent the questionnaires to all unsuccessful applicants ${ }^{[7]}$ (there was no sampling). For the unsuccessful applicants 3,000 questionnaires were sent and 1,048 received. The survey was carried out in July 2012. The relatively low number of questionnaires received is partly linked to the specific population and their housing conditions because in several cases their current housing condition is not a stable one and therefore their addresses change. Even though the response rate was somewhat lower, due to the fact that the population studied consists of people that are very hard to reach through any other means, we feel that the survey successfully targeted the population studied and can therefore provide relevant data on those at risk of housing exclusion.

It should also be noted that the applicants for social housing are divided into two lists. List $\mathrm{A}$ includes applicants with somewhat lower-than-average income, and List B is applicants with higher income. ${ }^{[8]}$ The municipality usually defines how many dwellings are intended for applicants from each list for each call. Applicants on List B are obliged to pay for their own participation (a payment of $10 \%$ of the price of the housing, which is returned after ten years living in the housing with
Table 2: Education, employment and sex by type of applicant

\begin{tabular}{|c|c|c|c|c|}
\hline & \multicolumn{2}{|c|}{ List A } & \multicolumn{2}{|c|}{ List B } \\
\hline & $n$ & $\%$ & $n$ & $\%$ \\
\hline \multicolumn{5}{|l|}{ Education } \\
\hline Did not complete primary school & 25 & 2.8 & 0 & 0.0 \\
\hline Completed primary school & 143 & 15.8 & 4 & 3.5 \\
\hline Vocational high school & 374 & 41.2 & 23 & 20.4 \\
\hline High school & 227 & 25.0 & 35 & 31.0 \\
\hline Vocational college & 49 & 5.4 & 12 & 10.6 \\
\hline Bachelor's degree & 80 & 8.8 & 34 & 30.1 \\
\hline Master's degree, $\mathrm{PhD}$ & 9 & 1.0 & 5 & 4.4 \\
\hline \multicolumn{5}{|l|}{ Employment } \\
\hline Self-employed & 57 & 6.3 & 7 & 6.1 \\
\hline Employed long-term contract & 397 & 43.8 & 79 & 69.3 \\
\hline Employed short-term contract & 116 & 12.8 & 14 & 12.3 \\
\hline Employed at a bankrupt company & 3 & 0.3 & 0 & 0.0 \\
\hline $\begin{array}{l}\text { Unemployed less than twelve } \\
\text { months }\end{array}$ & 60 & 6.6 & 3 & 2.6 \\
\hline $\begin{array}{l}\text { Unemployed more than twelve } \\
\text { months }\end{array}$ & 115 & 12.7 & 2 & 1.8 \\
\hline Student & 20 & 2.2 & 0 & 0.0 \\
\hline Retired & 79 & 8.7 & 7 & 6.1 \\
\hline Housewife & 1 & 0.1 & 0 & 0.0 \\
\hline Unable to work & 40 & 4.4 & 1 & 0.9 \\
\hline Other & 18 & 2.0 & 1 & 0.9 \\
\hline \multicolumn{5}{|l|}{ Sex } \\
\hline Male & 365 & 40.0 & 55 & 48.2 \\
\hline Female & 547 & 60.0 & 59 & 51.8 \\
\hline Total & 912 & 100.0 & 114 & 100.0 \\
\hline
\end{tabular}

Table 3: Average income of household / household member

\begin{tabular}{lll}
\hline & List A & List B \\
\hline Average & 398.46 & 714.64 \\
\hline Standard deviation & 294.27 & 432.95 \\
\hline Total & 849 & 110 \\
\hline
\end{tabular}

Table 4: Average housing costs as share of household income (in \%)

\begin{tabular}{lll}
\hline & List A & List B \\
\hline Rent & 43.86 & 28.59 \\
\hline Housing costs (without heating) & 16.47 & 9.61 \\
\hline Heating (yearly) & 12.85 & 5.83 \\
\hline Heating (in season) & 16.25 & 8.21 \\
\hline All housing costs & 49.54 & 22.64 \\
\hline
\end{tabular}

Note: Respondents could choose to give answers on costs separately or in total, and so different respondents answered these questions. 
Table 5: Previous and current housing status of applicants (in \%)

\begin{tabular}{lllll}
\hline & List A & \multicolumn{2}{l}{ List B } \\
\hline (Co)owner & Previous & Current & Previous & Current \\
\hline Private rental & 29 & 0.9 & 5.6 & 0.9 \\
\hline Living in housing owned by parents* (with them) & 40.8 & 53.7 & 42.6 & 57.1 \\
\hline Living in housing owned by parents* (without them) & 28.1 & 21.3 & 27.8 & 18.8 \\
\hline In work hostels & 3.5 & 4.1 & 4.6 & 5.4 \\
\hline In an emergency unit & 3.6 & 1.3 & 3.7 & 6.3 \\
\hline In a place not intended for habitation (garage, etc.) & 2.2 & 4.9 & 2.8 & 0.0 \\
\hline In a safe house, maternity home, shelter, etc. & 4.7 & 2.5 & 0.9 & 0.0 \\
\hline Denationalised rental housing & 1.0 & 0.4 & 0.9 & 0.9 \\
\hline Janitor's dwelling & 2.4 & 1.6 & 2.8 & 0.0 \\
\hline Temporary with friends & 1.0 & 1.0 & 0.9 & 0.9 \\
\hline Other & 3.6 & 4.4 & 2.8 & 3.6 \\
\hline Total & 6.0 & 3.9 & 4.6 & 6.3 \\
\hline
\end{tabular}

Note: *Parents or other relatives.

Table 6: Housing conditions

\begin{tabular}{lllll}
\hline & List A & \multicolumn{3}{l}{ List B } \\
\hline & $n$ & $\%$ & $n$ & $\%$ \\
\hline No toilet & 190 & 21.9 & 16 & 14 \\
\hline No bathroom & 185 & 21.2 & 14 & 12.3 \\
\hline No kitchen & 179 & 20.7 & 17 & 15 \\
\hline Not sufficiently heated & 160 & 18.5 & 13 & 11.4 \\
\hline $\begin{array}{l}\text { Problems with dampness } \\
\text { and leaks }\end{array}$ & 364 & 41.8 & 26 & 23.2 \\
\hline Not enough daylight & 237 & 26.7 & 13 & 11.5 \\
\hline Old plumbing, old heating & 356 & 40.7 & 37 & 32.7 \\
\hline
\end{tabular}

Table 7: Average housing size per household member $\left(\mathrm{m}^{2}\right)$

\begin{tabular}{lll}
\hline & List A & List B \\
\hline Average & 14.92 & 20.75 \\
\hline Standard deviation & 9.71 & 12.23 \\
\hline Median & 13 & 18 \\
\hline
\end{tabular}

a $2 \%$ interest rate), and for them a higher spatial standard is applied (e.g., for a household with three members on List A, the size of the housing is 45 to $55 \mathrm{~m}^{2}$, whereas for the same household on List B the standard is 45 to $70 \mathrm{~m}^{2}$ ). Because this is an important distinction, some of the results are divided by these two groups.

\subsection{Description of the respondents}

In this section we present the demographic data, financial situation and housing situation of the respondents; that is, appli- cants for social housing in the Municipality of Ljubljana (see Tables 1, 2 and 3). The majority of households have a low income (see Table 3). As could be expected, the income is lower among applicants on List A (EUR 398 per household member) and higher among those on List B (EUR 714 per household member). The applicants also have high housing costs (see Table 4). For those paying rent, this rent represents a high share of household income (for $44 \%$ of applicants on List A). Even for applicants on List B, they are close to 30\%, which is the limit that usually defines a housing cost overburden (see Cirman, 2006). When summarising costs, it is safe to say that applicants on List A are significantly overburdened with housing costs. It is therefore not surprising that people report that they also often run out of money for food (in the last six months, $42 \%$ of applicants on List A and $17 \%$ of applicants on List B).

As presented in Table 5, the majority of applicants are renters in the private rental sector $(54 \%$ on List $A$ and $57 \%$ on List B). A significant share do not have a legal contract (13.5\% on List $\mathrm{A}$ and $19 \%$ on List $\left.\mathrm{B}^{[9]}\right)$. The second most common option is living in housing owned by relatives. A significant share of applicants live in conditions that could be described as housing exclusion or homelessness (see Edgar et al., 2002); that is, temporarily with friends, in outbuildings, garages or similar. Comparing the previous and current housing status, it is sees that among applicants on Lists A and B the number of those in private rental housing has increased, mainly due to the decreasing number of those living with parents or relatives. The number of homeowners has also decreased. There is a worrisome trend of increasing shares living in housing situations that are defined as homeless (i.e., those living temporar- 
ily with friends) by some classifications (e.g., the European typology of homelessness and housing exclusion). However there is no clear trend that the housing situation is improving or deteriorating in the population observed. The households surveyed also live in poor housing conditions because a significant share do not have their own toilet (14\% on List B and $22 \%$ on List A), and similar shares are without a kitchen or bathroom, or in insufficiently heated housing (see Tables 6 and 7). The most common problem is dampness and leaks (more than $40 \%$ among those on List A, and 23\% among those on List B). Households also live in small dwellings because those on List A have on average only 13 to $15 \mathrm{~m}^{2}$ per person, whereas applicants on List $B$ have more than $20 \mathrm{~m}^{2}$ per person on average and therefore have a generally appropriate housing size.

\section{Resources and coping with housing exclusion and poverty}

Observing resources and coping strategies can offer important insight into housing exclusion and poverty of vulnerable groups and has important implications for provision of various housing alternatives, which are the focus of this article, and so we briefly present these resources. József Hegedus (2011) noted that affordability problem of housing can often be tackled in transition countries through the informal economy, realising housing equity or using remittances. Household strategies include several elements at the same time, such as applying for additional income benefits, taking on informal jobs, obtaining help from family or migration of family members. Here we present some of the resources and coping strategies of applicants, which we have divided into four categories: 1) welfare state support, 2) family support, 3) NGO support and 4) individual strategies (use of savings, etc.). We base our understanding of coping on the notion developed by psychologists, which is described as cognitive and behavioural efforts to manage external demands (Lazarus \& Folkman, 1984) and therefore define coping capacities as resources and relationships, behaviour and mental activities that allow people to improve their lives or protect themselves from a negative outcome (see SchroderButterfill \& Marianti, 2006; Filipovič Hrast et al., 2012). Coping strategies and resources can therefore indicate the possibility that the excluded have in exiting their housing deprivation.

\subsection{Welfare state support}

Welfare support is crucial for the majority of applicants in emergency units and is also significant for those on List A. Most important are social benefits (19\% of those on List A). Similarly, one-time financial aid from centres for social work has also been used by this group. Applicants on List B rely less on this type of support. Social benefits are more frequent
Table 8: Welfare and other support

\begin{tabular}{lllll}
\hline & List A & \multicolumn{3}{l}{ List B } \\
\hline & $n$ & $\%$ & $n$ & $\%$ \\
\hline Receives social benefits & 151 & 19.2 & 10 & 9.3 \\
\hline $\begin{array}{l}\text { Received financial assistance from } \\
\text { a centre for social work* }\end{array}$ & 138 & 16.7 & 1 & 1.0 \\
\hline Income supplement & 48 & 7.0 & 1 & 1.1 \\
\hline Disability benefit & 69 & 9.8 & 4 & 4.0 \\
\hline
\end{tabular}

Note: *This is one-time financial assistance.

among single parents and single households, whereas income supplement, ${ }^{[10]}$ as could be expected, is more common among older and single households (see Table 8).

\subsection{Family and NGO support}

Slovenia has strong family ties, and social network research shows strong connections between family members (Hlebec et al., 2010). The significance of family support in housing is common to many transition countries (Mandic, 2008). The country can also be described as familialistic, similar to other southern European countries, with cohabitation also an important part of support between family members (Ogg, 2005; Hank, 2007). Consequently we can expect that support from family will be strong. Similarly, Hegedus (2011) noted that the consequence of the affordability problem with regard to housing access in transition countries was the increasing role of intergenerational transfers (family savings and inheritance). In Slovenia, along with financial support (for purchasing housing or general living), one of the characteristic types of family support is also providing construction land or a house (living in a common household or optionally adapting the existing family home for two households; Cirman, 2006). The first and perhaps most important form of family support is providing a place to live. Among applicants on List A, 25.4\% live in housing owned by parents or other relatives (together with them or without), and there is a similar share among applicants on List B (24.2\%). A significant share also received financial help from relatives in the last six months: $40.6 \%$ among applicants on List A, and $26.1 \%$ among applicants on List B (see Table 9). Since Slovenia's independence in 1991, the role of NGOs has been increasing in supplying services and different kinds of support for most vulnerable groups. Among applicants on List A, this type of support is present (17\%), whereas it is almost non-existent among applicants on List $\mathrm{B}$ (less than $1 \%)$. This small share is somewhat surprising given that that a significantly higher share of respondents have run out of food in the last six months but have not received NGO support. These results indicate that such support is usually the last resource to draw upon and that other resources are used 
Table 9: NGO and family support

\begin{tabular}{lllll}
\hline & List A & \multicolumn{3}{l}{ List B } \\
\hline & $n$ & $\%$ & $n$ & $\%$ \\
\hline $\begin{array}{l}\text { Received financial help from } \\
\text { relatives }\end{array}$ & 350 & 40.6 & 29 & 26.1 \\
\hline $\begin{array}{l}\text { Received help from an NGO } \\
\text { in the last six months }\end{array}$ & 146 & 17.3 & 1 & 0.9 \\
\hline $\begin{array}{l}\text { Living in housing owned by } \\
\text { relatives (with them) }\end{array}$ & 192 & 21.3 & 21 & 18.8 \\
$\begin{array}{l}\text { Living in housing owned by } \\
\text { relatives (without them) }\end{array}$ & 37 & 4.1 & 6 & 5.4 \\
\hline
\end{tabular}

Table 10: Loans and savings of households

\begin{tabular}{|c|c|c|c|c|}
\hline & List $\mathrm{A}$ & & List B & \\
\hline & $n$ & $\%$ & $n$ & $\%$ \\
\hline Have loans & 402 & 45.4 & 68 & 60.2 \\
\hline Average monthly loan (EUR) & 323.48 & & 357.24 & \\
\hline In arrears & 84 & 20.9 & 11 & 16.2 \\
\hline Have no savings* & 658 & 76.5 & 66 & 60.6 \\
\hline $\begin{array}{l}\text { Had savings that were significan- } \\
\text { tly reduced during the last year }\end{array}$ & 60 & 7.0 & 8 & 7.3 \\
\hline $\begin{array}{l}\text { Had savings and that were } \\
\text { somewhat reduced during the } \\
\text { last year }\end{array}$ & 47 & 5.5 & 10 & 9.2 \\
\hline
\end{tabular}

Note: *Have no savings above EUR 500.

before this one. Use of NGO support is slightly higher among single households and single parents (calculations not shown).

\subsection{Individual strategies}

Among individual strategies, we observe how households save money or use savings and loans. Loans can be seen as a past strategy for improving living circumstances, which however can have severe negative effects on the current situations of applicants. Several households have loans: among those on List A 45\% and for List B 60\% (see Table 10). Among the applicants, a significant share of applicants have fallen behind in repayment of loans (21\% for List A and $16 \%$ for List B). The majority of applicants have practically no savings greater than EUR 500. Consequently, the use of one's own savings is not a common strategy. Among applicants on List A, 12.5\% have used their own savings, and among those on List B this share was $16.5 \%$. In resolving their housing situation, we asked about two kinds of strategies: saving to buy housing and applying for social housing. It is not surprising that only a small share of households are able to save and, as could be expected, this share is a little higher among applicants on List B (10\%) compared to List A (7\%). On average, the applicants applied for social housing two or three times, least often for those on
Table 11: Share of those that find the following housing options acceptable

\begin{tabular}{|c|c|c|c|c|}
\hline & \multicolumn{2}{|c|}{ List A } & \multicolumn{2}{|c|}{ List B } \\
\hline & $n$ & $\%$ & $n$ & $\%$ \\
\hline Smaller social rental housing & 723 & 82.8 & 82 & 72.6 \\
\hline $\begin{array}{l}\text { Housing built to passive } \\
\text { standards }\end{array}$ & 542 & 63.9 & 67 & 59.3 \\
\hline Shared homeownership & 537 & 63.3 & 84 & 74.3 \\
\hline Temporary social housing & 394 & 45.8 & 55 & 48.7 \\
\hline A housing cooperative & 393 & 49.6 & 65 & 61.9 \\
\hline $\begin{array}{l}\text { Cheaper purchase on the } \\
\text { market }\end{array}$ & 235 & 28.2 & 49 & 43.4 \\
\hline
\end{tabular}

List $B$ (the average is 1.94 times), and most often for those on List A (the average is 2.71 times).

\section{Acceptability of different housing options}

The survey examined the acceptability of various housing options for the applicants, which along with their resources also indicates the potential acceptability of various housing solutions and therefore has important policy implications. The applicants rated the acceptability of the following alternatives:

- Smaller social housing (with a larger number of rooms). The option that was offered is that social housing that would be offered would have a smaller spatial standard than that currently in use (i.e., smaller housing for the specific number of persons in the household); however, to still enable some privacy the number of rooms would be greater than what one would usually have for housing of such size.

- Housing built to passive standards. The option that was offered is an energy-efficient building with regulated temperature and no possibility of opening the windows. This would imply lower housing costs.

- Shared homeownership. For those applicants that would be entitled to social housing, but have some resources, the Public Housing Fund would help in purchasing housing by purchasing up to $40 \%$ of the dwelling. This share must be bought by the applicant over the course of fifteen years. During this time, the applicant pays the Public Housing Fund for the use of part of the dwelling (similar to non-profit rent).

- Temporary social housing. The option offered was that housing owned by a private landlord would be rented by the Public Housing Fund, which would then be sublet to the applicant at the price of social rental housing This would temporarily increase the social housing stock; however, the rental agreement would not be indefinite as with social housing, but limited to three years. 
Table 12: Results of cluster analysis: the three groups by acceptability of housing options

\begin{tabular}{lllllll}
\hline & $\begin{array}{l}\text { Smaller social } \\
\text { rental }\end{array}$ & Passive standards & $\begin{array}{l}\text { Shared owner- } \\
\text { ship }\end{array}$ & $\begin{array}{l}\text { Temporary social } \\
\text { rental (through } \\
\text { private landlord) }\end{array}$ & $\begin{array}{l}\text { Housing } \\
\text { cooperative }\end{array}$ & Cheaper purchase of housing \\
\hline $1(n=353)$ & 4.36 & 3.52 & 4.25 & 2.55 & 3.32 & 2.76 \\
\hline $2(n=294)$ & 4.56 & 4.41 & 4.11 & 4.49 & 4.74 & 3.35 \\
\hline $3(n=177)$ & 4.11 & 3.25 & 2.16 & 2.15 & 1.14 & 1.15 \\
\hline Total & 4.38 & 3.78 & 3.75 & 3.15 & 3.36 & 2.63 \\
\hline
\end{tabular}

Note: Variance analysis showed statistically significant differences between groups $(a=0.05)$.

- A housing cooperative. With the aid of the Public Housing Fund several applicants (e.g., thirty) would form a cooperative that would decide on the costs and specifics of a building. This would be financed through a loan and the loan repaid from the rent paid by members of the cooperative, who could also become homeowners in the end.

- Cheaper purchase of housing on the market. The option offered was that the Public Housing Fund would offer new housing for purchase; purchase would also be possible through shared ownership with the Public Housing Fund. ${ }^{[11]}$

Table 11 shows how acceptable these different housing alternatives were. The acceptability of housing alternatives varies between $28 \%$ of respondents (for purchase on the market) and $83 \%$ for smaller social rental housing. However, in general the majority of options seem to be acceptable to approximately half of respondents. In order to identify different groups of respondents with regard to the acceptability of various housing options, we used hierarchical clustering with a squared Euclidean distance and Ward's method. ${ }^{[12]}$ Based on the dendogram obtained, the respondents were divided into three distinct groups in relation to the alternative housing options that were offered. These groups are:

1. Those preferring shared homeownership and social rental housing. For this group, these two options are the only highly acceptable options, whereas they are more reserved regarding the other options (with averages mainly below the averages of the total sample). This is also the largest group.

2. Those open to all alternatives: the averages for the majority of alternatives are high (and above the averages of the total sample), indicating their high acceptance of each of the alternatives offered. This is the second-largest group, indicating that a large share of applicants is open to several alternatives when it comes to resolving their housing situation.

3. Those having a strong preference for social rental housing. In this group, the majority of alternatives was not acceptable at all (for many options the averages were below 2 on a scale of $1=$ absolutely not acceptable to $5=$ absolutely acceptable, and were below the average of the total sample), and the only acceptable option would be smaller social rental housing. This group is the smallest of the three; however, it still represents a significantly high share of the respondents.

These three groups are distinctive in terms of some of their demographic, household and other socioeconomic characteristics (see Table 12). Those belonging to Group 1 have a slightly higher income than other applicants in the sample, and the share of those with savings is again slightly higher than in the other two groups. In these groups there is also a slightly higher share of those living with their parents (or in their parent's dwelling). In this group there is also the highest share of large households (i.e., five people or more). This indicates that the largest group of applicants would also consider purchasing housing, and they most likely have the necessary resources to do so (with higher income, savings and also potential family support indicated by their current living situation). Due to the low accessibility of loans (as indicated in the first part of this article), they have difficulty entering the homeownership sector on their own and would need some other instruments enabling them to enter this market, such as that offered by shared homeownership. This would than lead to less pressure on the social rental sector. The second largest group (Group 2), those most open to all alternatives, are more often male, the share of those with lowest income is higher in this group than in the whole sample, the share of those in private rental housing is also higher than in the total sample, and the share of those with higher education is the highest. This group seems to be quite desperate to leave the private rental sector (which could be linked to high rental prices and their generally low income) and is very open to various alternatives. For the members of this group, housing cooperatives seem to be the preferred option, which indicates that this alternative would attract a specific group if they received appropriate support in pursuing this way of improving their housing situation. They also seem to be willing to invest their time, work and effort into setting up a cooperative, and also seem to have the skills (a higher share of those with higher education).

The two groups above therefore seem to be the ones that have the highest motivation and also potential resources that would enable them to improve their housing situation outside the 
Table 13: Selected socio-demographic characteristics of the groups (in percentages)

\begin{tabular}{lllll}
\hline & $\begin{array}{l}\text { Group 1 } \\
(n=353)\end{array}$ & $\begin{array}{l}\text { Group 2 } \\
(n=294)\end{array}$ & $\begin{array}{l}\text { Group 3 } \\
(n=177)\end{array}$ & $\begin{array}{l}\text { Total average } \\
(n=814)\end{array}$ \\
\hline Share of retired & 2.3 & 3.1 & 15.9 & 6.2 \\
\hline Share without savings & 67.9 & 77.7 & 78.0 & 73.5 \\
\hline Share living in private rental housing & 49.6 & 59.9 & 51.7 & 53.7 \\
\hline Share of single households & 11.0 & 15.8 & 24.4 & 15.6 \\
\hline Share with higher education & 22.4 & 26.7 & 7.9 & 20.8 \\
\hline Share with household income less than EUR 900 & 32.7 & 46.6 & 52.7 & 41.9 \\
\hline Share of men & 37.4 & 50.3 & 36.7 & 41.9 \\
\hline
\end{tabular}

social rental sector; however, they are without any alternative options that would currently aid them in this effort. The last group (Group 3) is the smallest, and for them social housing seems to be the best (and most likely only) solution for their housing vulnerability. Those preferring social rental housing are usually older, more often single households with lower education. The share of women is higher in this group than in the total sample. They also have a lower household income. For this group, social housing seems to be the best alternative.

\section{Conclusion}

As Hegedus (2011) argues, in the new post-transition environment social agencies do not have the capacity or resources to operate an efficient safety net and provide help to the neediest families. We can definitely see this in Slovenia, where the living situations of applicants for social housing indicate their high financial and housing vulnerability and consequently poor resources to seek other housing option. This is especially true for applicants on List A (without their own contribution), who have very low incomes, and often have financial problems and few resources (either in terms of savings or family help). Looking at how numerous this group is, one could claim that it is primary for the social housing sector to develop and to be able to respond to their needs. As Nicholas Pleace et al. (2012) have said, any increase, however small, in adequate and affordable housing options is desirable.

However the current policy does not seem to be inclined toward developing social housing. The crisis has additionally decreased funds for this sector, and the new proposal for the 2013-2022 Housing Programme ${ }^{[13]}$ (in the draft phase) does not emphasise the need for an increase in the public rental sector, but lists a new form of rent subsidy (however, along with the need for an increase in non-profit rents) and shared homeownership among the solutions for increasing accessibility of housing for vulnerable groups, and proposes selling public housing to sitting tenants as a possible option. ${ }^{[14]}$ This indicates that there is very little national support for the need to increase this rental stock. However, even though our research indicated that the applicants do not have numerous resources available and often rely on welfare aid and family support, and that they also have high debts and low incomes, they must be seen as those actively trying to find solutions to their housing situation, and the state and local actors should try to support them in their activities. This article hay analysed some possible additional instruments that would enable those in more difficult housing situations to address this and find solutions outside the already overburdened social rental sector. We have looked at the acceptability of various housing alternatives to social housing among the applicants. The analysis has indicated the existence of three distinct groups. For one group, there seem to be no alternative to social housing, and they are generally older, retired people, with low incomes. However, this is also the smallest group and, if the needs of other groups were addressed in different ways, the social housing sector would potentially more easily address their needs. Those in the second group seem to be open to all options, and are generally more highly educated, with low incomes and to a large extent trying to leave the private rental sector. Among the most preferred options for this group are housing cooperatives. There seems to be a specific target group that would use this instrument if they received sufficient support (from the state and/or local actors). The last group includes those that generally have slightly more means and are more inclined toward shared homeownership than all other groups, which also relates to their slightly higher available resources (income and savings).

Local actors, such as the municipalities, seem to have the primary role not only in developing social housing but also in searching for these new solutions and innovative housing options. There is therefore definitely a trend of hollowing out of the state and its transfer of responsibility to lower levels (see Edgar et al., 2002). This role is becoming increasingly complex and innovative solutions are also already being sought based on these needs; for example, their cooperation with NGOs in developing housing support for those living in emergency units and renting out emergency units to NGOs working with the homeless or other vulnerable groups in the Municipality of 
Ljubljana. These solutions should however add to the existing supply of housing and not replace the existing supply. In addition, specific attention should be directed to maintaining existing standards. There is a danger that these innovative solutions are also moving in the direction of reducing the costs of supplying housing and decreasing standards under financial pressure. Such examples are so-called emergency units, which can (and already in some cases have) become permanent living arrangements and which offer substandard living conditions to their tenants. People in housing need also seem to have a relatively high acceptance of lower standards (e.g., high acceptability of smaller social housing among the respondents). Last, but not least, our findings can add to the "welfare dependence" debate because they clearly show how applicants for social housing vary with regard to their readiness and capability to engage more actively to obtain housing. A smaller group of people with the lowest means are reluctant regarding other options, whereas the majority of claimants show great readiness for more active engagement if there were such an opportunity. This is creating more increasingly diverse opportunities for housing, which seems to be the key housing policy challenge.

\section{Srna Mandič}

University of Ljubljana, Faculty of Social Sciences, Ljubljana, Slovenia E-mail: srna.mandic@fdv.uni-lj.si

Maša Filipovič Hrast

University of Ljubljana, Faculty of Social Sciences, Ljubljana, Slovenia E-mail: masa.filipovic@fdv.uni-lj.si

\section{Notes}

[1] Prices have been increasing as the supply lags behind the growing demand. The reasons lie in unimplemented systemic solutions that affected the availability of real estate on the market (e.g., unclear ownership situations, legal procedures, etc.). After 2008, prices began to fall and demand significantly decreased.

[2] One reason is the poor accessibility of housing loans, and consequently housing purchases largely depended on family support (in terms of loans, and also construction land; Cirman, 2006; Andrews et al., 2011). Consequently share of homeowners with a mortgage is very low, only $7 \%$ of the population, and the share of homeowners without a mortgage is $80 \%$ of the population (Mandic, 2012). The situation is similar in other CEE countries, as Hegedus (2011) stated, and even the most developed transition countries are behind the EU because the average ratio of outstanding loans to GDP is 7\% in CEE countries whereas in the $\mathrm{EU}$ it is $38 \%$.

${ }^{[3]}$ Some local authorities also provide so-called emergency housing units (e.g., in the Municipality of Ljubljana). These differ from social housing because they are temporary and the living standards are lower than in social housing (smaller housing, and a shared kitchen and/or bathrooms).

${ }^{[4]}$ Currently there are 160 applicants for 223 units (which are currently rented out). Waiting for single person can take four years (Dekleva, 2013).

${ }^{[5]}$ See, for example, Huston Gibson and Yanmei Li (2013) for a discussion of condominiums as an affordable housing option.
${ }^{[6]}$ Document on innovative and effective approaches to housing.

${ }^{[7]}$ The fact that questionnaires were sent to the applicants by the Public Housing Fund might have had a negative effect on the reliability of the answers given; however this could not be helped because the protection of individual information meant that the researchers did not have access to the addresses themselves.

${ }^{[8]}$ In the last call for applications, among 350 dwellings 120 were intended for applicants on List B (with their own contribution).

${ }^{[9]}$ This is similar to the results of the national housing survey, in which $14 \%$ had no legal rental contract (Mandic \& Cirman, 2006).

${ }^{[10]}$ Income supplements are intended for older people with pensions that are below subsistence level and those that are permanently incapable of working.

${ }^{[11]}$ The purchase price mentioned was EUR $2,000 / \mathrm{m}^{2}$, which was still a relatively high price, especially in the context of falling market prices.

${ }^{[12]}$ The variables used for clustering were acceptability of housing alternatives: smaller social housing, housing built to passive standards, shared homeownership, temporary social housing, a housing cooperative (and additional willingness to invest personal work, time and effort in this project) and cheaper purchase of housing on the market.

${ }^{[13]}$ Ministry of Infrastructure and Spatial Planning.

${ }^{[14]}$ It is however emphasised that the housing stock should not decrease due to this, and that housing that is sold should be replaced by new units.

\section{References}

Andrews, D., Caldera Sánchez A. \& Johansson, A. (2011) Housing markets and structural policies in OECD countries. OECD Economics Department Working Papers, No. 836, OECD Publishing. DOI: $10.1787 / 5 \mathrm{kgk} 8 \mathrm{t} 2 \mathrm{k} 9 \mathrm{vf3}-\mathrm{en}$

Baldini, M. \& Poggio, T. (2012) Housing policy towards the rental sector in Italy: A distributive assessment. Housing Studies, 27(5), pp. 563-581. DOI: 10.1080/02673037.2012.697549

Blessing, A. (2012) Magical or monstrous? Hybridity in social housing governance. Housing Studies, 27(2), pp. 189-207. DOI: 10.1080/02673037.2012.649469

Cirman, A. (2006) Kako dosegljiva so stanovanja. In: Mandic, S. \& Cirman, A. (eds.) Stanovanje v Sloveniji 2005, pp. 55-70. Ljubljana, University of Ljubljana, Faculty for Social Sciences.

Cirman, A. (2007) Razvoj stanovanjskega trga v Sloveniji: pogled z vidika stanovanjskega financiranja. In: Sendi, R. (ed.) Stanovanjska reforma: pričakovanja, potrebe, realizacija, pp. 53-82. Ljubljana, Urbani izziv - publikacije.

Clapham, D., Hegedus, J., Kintrea, K. \& Tosics, I. (eds.) (1996) Housing privatization in Eastern Europe. London, Greenwood Press.

Dekleva, J. (2013) Conference proceedings. Ljubljana, University of Ljubljana, Faculty of Education.

Dwyer, P. (2004) Agency, "dependency" and welfare: Beyond issues of claim and contribution? In: Harteley, D. (ed.) The ethics of welfare, pp. 135-154. Bristol, Policy Press.

Edgar, B., Doherty, J. \& Meert, H. (2002) Access to housing: Homelessness and vulnerability in Europe. Bristol, Policy Press.

Edgar, B. \& Meert, H. (2005) Fourth review of statistics on homelessness in Europe. Developing an operational definition of homelessness. Brussels, Feantsa. 
Eurostat (2014) EU SILC data. Available at: http://ec.europa.eu/eurostat (accessed 1 Mar. 2014).

Filipovič, M. \& Mandic, S. (2007) Housing vulnerability in Municipality of Ljubljana [sic]. Urbani izziv, 18(1), pp. 65-76.

DOI: 10.5379/urbani-izziv-en-2007-18-01-02-008

Filipovič Hrast, M., Hlebec, V. \& Kavčič, M. (2012) The social exclusion of the elderly: A mixed-methods study in Slovenia. Sociologický časopis, 48(6), pp. 1051-1074.

Fitzpatrick, S. \& Pawson, H. (2014) Ending security of tenure for social renters: Transitioning to "ambulance service" social housing? Housing Studies, 29(5), pp. 597-615. DOI: 10.1080/02673037.2013.803043

Forrest, R. (2014) Public housing futures. Housing Studies, 29(4), pp. 463-466. DOI: 10.1080/02673037.2014.912867

Gibson, H. J. \& Li, Y. (2013) Opportunities for the United States condominium foreclosure market to provide amenable affordable housing options: The case of Tampa/Hillsborough, Florida. Urbani izziv, 24(1), pp. 90-106. DOI: 10.5379/urbani-izziv-en-2013-24-01-001

Hank, K. (2007) Proximity and contacts between older parents and their children: A European comparison. Journal of Marriage and Family, 69(1), pp. 157-173. DOI: 10.1111/j.1741-3737.2006.00351.x

Hegedus, J. (2011) Social safety nets, the informal economy and housing poverty - experiences in transitional countries. European Journal of Homelessness, 5(1), pp. 15-26.

Hegedus, J., Mayo, E. \& Tosics, I. (1996) Transition of the housing sector in the east-central European countries. Budapest, Metropolitan Research Institute.

Hegler, J. (2006) Ljubljančanke in Ljubljančani imamo najbolj pestro stanovanjsko oskrbo v Republiki Sloveniji. Glasilo Mestne občine Ljubljana, 7(11), pp. 4-15.

Hlebec, V., Filipovič Hrast, M. \& Kogovšek, T. (2010) Social networks in Slovenia: Changes during the transition period. European Societies, 12(5), pp. 697-717. DOI: 10.1080/14616696.2010.483009

Hulse, K. \& Haffner, M. (2014) Security and rental housing: New perspectives. Housing Studies, 29(5), pp. 573-578.

DOI: 10.1080/02673037.2014.921418

Hulse, K. \& Milligan, V. (2014) Secure occupancy: A new framework for analysing security in rental housing. Housing Studies, 29(5), pp. 638656. DOI: $10.1080 / 02673037.2013 .873116$

Kušar, S. (2012) Selected spatial effects of the global financial and economic crisis in Ljubljana, Slovenia. Urbani izziv, 23(2), pp. 112-120. DOI: 10.5379/urbani-izziv-en-2012-23-02-004

Lazarus, R. S. \& Folkman, S. (1984) Stress, appraisal, and coping. New York, Springer Publishing Company.

Leather, P. \& Nevin, B. (2013) The housing market renewal programme: Origins, outcomes and the effectiveness of public policy interventions in a volatile market. Urban Studies, 50(5), pp. 856-875. DOI: $10.1177 / 0042098012449667$

Lévy-Vroelant, C. (2014) Contradictory narratives on French social housing: Looking back and looking forward. Housing Studies, 29(4), pp. 485500. DOI: $10.1080 / 02673037.2014 .882498$

Lux, M. \& Mikeszova, M. (2012) Property restitution and private rental housing in transition: The case of the Czech Republic. Housing Studies, 27(1), pp. 77-96. DOI: 10.1080/02673037.2012.629643

Lux, M. \& Sunega, P. (2014) Public housing in the post-socialist states of central and eastern Europe: Decline and an open future. Housing Studies, 29(4), pp. 501-519. DOI: 10.1177/0042098011405693
Mandic, S. (2007) Učinki tranzicijskih politik na stanovanjsko oskrbo v socialnem/neprofitnem sektorju. In: Sendi, R. (ed.) Stanovanjska reforma: pričakovanja, potrebe, realizacija, pp. 15-32. Ljubljana, Urbani izziv publikacije.

Mandic, S. (2008) Home-leaving and its structural determinants in Western and Eastern Europe: An exploratory study. Housing Studies, 23(4), pp. 615-637. DOI: 10.1080/02673030802112754

Mandic, S. (2010) The changing role of housing assets in post-socialist countries. Journal of housing and the built environment, 25(2), pp. 213226. DOI: $10.1007 / \mathrm{s} 10901-010-9186-5$

Mandic, S. (2012) Home ownership in post-socialist countries: Between macro economy and micro structures of welfare provision. In: Ronald, R. \& Elsinga, M (eds.) Beyond home ownership: Housing, welfare and society, pp 68-88. London, Routledge.

Mandic, S. \& Cirman, A. (2006) Stanovanje v Sloveniji 2005. Ljubljana, University of Ljubljana, Faculty for Social Sciences.

Mandic, S. \& Filipovič Hrast, M. (2008) Homelessness "in transition": A Slovenian study. In: Doherty, J. \& Edgar, B. (eds.). In my caravan, I feel like superman: Essays in honour of Henk Meert 1963-2006. St. Andrews, FEANTSA, Centre for Housing Research.

Mandic, S. \& Cirman, A. (2012) Housing conditions and their structural determinants comparisons within the enlarged EU. Urban Studies, 49(4), pp. 777-793. DOI: 10.1177/0042098011405688

Mandic, S., Filipovič Hrast,M., Mrzel, M. \& Rozman, Z. (2012) Kako izboljšati ponudbo najemnih stanovanj v mestni občini Ljubljana: končno poročilo. Final report. Ljubljana, University of Ljubljana, Faculty for Social Sciences, Centre for Welfare Studies.

Meert, H., Edgar, B. \& Doherty J. (2004) Towards an operational definition of homelessness and housing exclusion. Paper presented at the ENHR conference Housing, Growth and Regeneration, 2-6 July, Cambridge. Typescript.

Morrison, N. (2013) Meeting the decent homes standard: London housing associations asset management strategies. Urban Studies, 50(12), pp. 2569-2587. DOI: 10.1177/0042098012474512

Muir, J. (2013) The dynamics of policy-making under UK devolution: Social housing in Northern Ireland. Housing Studies, 28(7), pp. 1081-1093. DOI: 10.1080/02673037.2013.803045

Ogg, J. (2005) Social exclusion and insecurity among older Europeans: The influence of welfare regimes. Ageing and Society, 25(1), pp. 69-90. DOI: $10.1017 /$ S0144686X04002788

Pawson, H. \& Sosenko, F. (2012) The supply-side modernisation of social housing in England: Analysing mechanics, trends and consequences. Housing Studies, 27(6), pp. 783-804. DOI: 10.1080/02673037.2012.714 462

Pittini, A. \& Laino, E. (2012) Housing Europe review 2012. The nuts and bolts of European social housing systems. Brussels, CHECODAS.

Pleace, N., Teller, N. \& Quilgars D. (2012) Social housing allocation and homelessness. Brussels, Feantsa.

Polacek, R., McDaid, D., Fernandez, J., Matosevic, T., Penn, H., Korintus, M. \& Verheyde, M. (2011) Study on social services of general interest. Final report. Brussels, European Commission, Directorate General for Employment, Social Affairs and Inclusion.

Public Housing Fund of the City of Ljubljana (2011) Stanovanjski program mestne občine Ljubljana za leti 2011 in 2012. Ljubljana.

Robinson, D. (2013) Social housing in England: Testing the logics of reform. Urban Studies, 50(8), pp. 1489-1504. DOI: $10.1177 / 0042098012462611$ 
Schroder-Butterfill, E. \& Marianti, R. (2006) A framework for understanding old-age vulnerabilities. Ageing and Society, 26(1), pp. 9-35. DOI: $10.1017 / S 0144686 \times 05004423$

Sendi, R. (2007) Stanovanjska reforma: pričakovanja, potrebe, realizacija. Ljubljana, Urbani izziv - publikacije.

Sendi, R. (2013) The low housing standard in Slovenia: Low purchasing power as an eternal excuse. Urbani izziv, 24(1), pp. 107-124.

DOI: 10.5379/urbani-izziv-en-2013-24-01-002

Statistical Office of the Republic of Slovenia (2011) Public census data. Available at: www.stat.si (accessed 3 Apr. 2014).

Struyk, R. (1996) Economic restructuring of the former Soviet bloc: The case of housing. Aldershot, Avebury.

Surveying and Mapping Authority of the Republic of Slovenia (2008) Kvartalno poročilo o povprečnih cenah nepremičnin na slovenskem trgu za 3. četrtletje 2008. Ljubljana.

Taylor-Gooby, P. (1993) Citizenship, dependency and the welfare mix. International Journal of Health Services, 23(3), pp. 455-474. DOI: 10.2190/GNRY-39A4-F80K-GEU9

Taylor-Gooby, P. (2001) Risk, contingency and the third way. Social Policy and Administration, 35(2), pp. 195-211.

DOI: $10.1111 / 1467-9515.00227$

Tsenkova, S. (2014) The housing policy nexus and people's responses to housing challenges in post-communist cities. Urbani izziv, 25(2), pp. 90-106. DOI: 10.5379/urbani-izziv-en-2014-25-02-002

Turner, B., Hegedus, J. \& Tosics, I. (eds.) (1992) The reform of housing in Eastern Europe and the Soviet Union. London, Routledge. 